\title{
GROWING UP WITH HIV/AIDS: A STUDY ON ADOLESCENTS WITH HIV/AIDS AND THEIR FAMILY CAREGIVERS
}

Ana Amélia Antunes Lima ${ }^{1}$ Eva Néri Rubim Pedro²

Lima AAA, Pedro ENR. Growing up with HIV/AIDS: a study on adolescents with HIV/AIDS and their family caregivers. Rev Latino-am Enfermagem 2008 maio-junho; 16(3):348-54.

This is an exploratory study with a qualitative approach, which looks at the adolescent process with HIV/AIDS. The purpose is to identify how the adolescent process occurs, from the perspective of these teenagers and their family caregivers. The investigation was performed in Porto Alegre, RS between May and July 2005, and the subjects were four adolescents and three caregivers. Data were collected by means of interviews, which were subject to the content analysis technique. The study revealed that both teenagers and family caregivers did not show concern with the changes typical of the period, especially regarding sexuality questions. Yet, the underlying diagnosis and coping with HIV remain in the family core in order to protect these agents against the stigma of the disease.

DESCRIPTORS: acquired immunodeficiency syndrome; adolescent; family; caregivers

\section{CRECIENDO CON VIH/SIDA: UN ESTUDIO CON ADOLESCENTES PORTADORAS DE VIH/ SIDA Y SUS CUIDADORAS FAMILIARES}

Es un estudio exploratorio con abordaje cualitativo, que trata del proceso de desarrollo de la adolescencia en portadoras de VIH/SIDA, con el objetivo de identificar cómo ocurre el proceso de la adolescencia, en la visión de estas adolescentes y de sus cuidadoras familiares.La investigación se realizó en Porto Alegre-RS, entre los meses de mayo y julio de 2005; los sujetos fueron cuatro adolescentes y tres cuidadoras. La colecta de las informaciones se hizo por medio de entrevistas que fueron sometidas a la técnica de análisis de contenido. El estudio reveló que las adolescentes y sus cuidadoras familiares, manifestaron preocupación con los cambios propios de ese período, especialmente en asuntos relacionados a la sexualidad. Se hizo evidente que el diagnóstico y la convivencia con el VIH permanecen ocultos en el contexto familiar, con el objetivo de proteger, a estos actores, del estigma de la enfermedad.

DESCRIPTORES: síndrome de inmunodeficiencia adquirida; adolescente; familia; cuidadores

\section{CRESCENDO COM HIV/AIDS: ESTUDO COM ADOLESCENTES PORTADORAS DE HIV/AIDS E SUAS CUIDADORAS-FAMILIARES}

Estudo exploratório com abordagem qualitativa, que trata do processo de adolescer de portadoras de HIV/AIDS, com o objetivo de identificar como ocorre o processo da adolescência, na ótica dessas adolescentes e de suas cuidadoras-familiares. A investigação foi realizada em Porto Alegre, RS, entre os meses de maio e julho de 2005, sendo que os sujeitos foram quatro adolescentes e três cuidadoras. A coleta das informações ocorreu por meio de entrevistas que foram submetidas à técnica de análise de conteúdo. O estudo revelou que tanto as adolescentes quanto suas cuidadoras-familiares não manifestaram preocupação com as transformações próprias do período, especialmente nas questões que envolvem a sexualidade. Evidenciou-se que o diagnóstico e a convivência com o HIV ainda permanecem velados no círculo familiar, visando a proteção desses atores com relação ao estigma da doença.

DESCRITORES: síndrome de imunodeficiência adquirida; adolescente; família; cuidadores

${ }^{1}$ M.Sc. in Nursing, Faculty, Centro Universitário Feevale, Brazil, e-mail: anninhaenf@hotmail.com; ${ }^{2}$ Ph.D. in Education, Faculty, Rio Grande do Sul Federa University, Brazil, e-mail: evaneri@terra.com.br 


\section{INTRODUCTION}

Adolescence is universal from the biological aspect, but it is modified and experienced distinctly according to cultures and each society's values, whose influences affect questions regarding education, health and human development.

The adolescent process includes, besides genetic components, values and knowledge acquired through life experiences which occur under the influence of the subject's socializing instances, represented by family, school and, more recently, the media $^{(1-2)}$.

One of the authors carried out an educational project with adolescents from a poor neighborhood in Porto Alegre, RS, Brazil. They were questioned on how they were experiencing the adolescent process, given that many doubts emerged when addressing topics related to development aspects. These activities permitted some reflection on how these healthy and happy adolescents were experiencing adolescence. During this project, it was observed that they still had questions about biopsychosocial changes typical of the period.

The same reflection that emerged from the contact with these adolescents was transported to another group of adolescents - HIV/AIDS patients infected by vertical transmission. The young people in this group, without any prediction of long-term survival, may not have received information regarding typical changes in adolescence, which are not constricted to the body itself, but include the blossoming of new ways of handling themselves and the world.

A study ${ }^{(3)}$ developed with children living with HIV showed that the birth of antiretroviral therapies, implemented since 1996, has allowed for a reduction in deaths and opportunist infections, providing the children and adolescents with quality survival and a future perspective. Thus, children born from women infected by HIV in the first decade of the epidemic have reached adolescence and are growing up and experiencing events similar to those experienced by adolescents of the same age, regardless of the routines imposed by coping with the HIV virus.

This paper looks at the adolescent process of girls with HIV/AIDS infected by vertical transmission, due to the fact that they belong to a large group of people born under the stigma of a disease that marginalizes people, not considering key aspects in human development. Studying the adolescence of this group has aroused the following research question: how do adolescents with HIV/AIDS perceive the adolescent process?

Based on this and other questions, the following objectives were designed: identifying how the adolescent process of adolescents with HIV/AIDS infected by vertical transmission occurs and reporting how the adolescents' family caregivers perceive this process.

\section{METHODOLOGY}

This is an exploratory study with a qualitative approach. Qualitative research is essentially interpretative and the researcher sees the social phenomena hollistically ${ }^{(4)}$, that is, this research approach provides the knowledge of a phenomenon from the point of view of the study participants, through their experiences in their natural environment.

The study context is a Specialized Care Service (SCS) located in the metropolitan region of Porto Alegre, which treats people with sexually transmitted diseases (STD) and AIDS, with the help of a multidisciplinary team. There were seven participants: three caregivers - two mothers with and one sister without HIV/AIDS - and four adolescents with HIV/AIDS between 11 and 14 years old, residing in the metropolitan region of Porto Alegre and treated at the SCS.

Data collection took place between May and July 2005, using two semistructured interview scripts guided by two themes: the adolescent process and coping with AIDS. One script was applied to the adolescents and the other was used individually with the caregivers. After their consent, their reports were recorded on a cassette tape. The interviews had been previously scheduled with the informants and held at a private room in the SCS.

The information obtained by means of interviews was subject to the content analysis technique ${ }^{(5)}$, in which the type of discourse and interpretation are evaluated. For the report analysis, this technique prescribes some steps, which were followed after the transcription process of the tapes. Among the prescribed steps for analysis, floating reading stands out, which consists of carefully reading the interviews, with a view to discovering the meanings of the participants' statments; exploration of the material, in which the reports are grouped and 
mapped and, finally, report reading in order to reorganize them and elaborate the final categories, which were subject to a discussion process in the light of pertinent literature.

Regarding the ethical aspects, the study was submitted, approved and protocolled by the Research Ethics Committee at the Maternal Child Hospital Presidente Vargas, affiliated with the municipal government of Porto Alegre, and registered under number $14 / 05$. Through the informed consent, the participants had the following items guaranteed: their anonymity, explanation of study-related doubts, as well as autonomy and voluntary nature of their participation in the research. After the researcher had read the document, it was signed by the participants and researcher in two identical copies.

\section{RESULTS}

The analysis of the information content permitted the final elaboration of two categories and four subcategories. The fist category was described as the adolescent process with HIV/AIDS from the adolescent standpoint. The following subcategories emerged: growth and development of the adolescent with HIV/AIDS and coping with HIV/AIDS: the diagnosis revelation, the adolescent feelings and reactions. The second category, called adolescent process with HIV/ AIDS from the family caregivers' standpoint, shows the subcategories growth and development of adolescents with HIV/AIDS from the family caregivers' standpoint and the diagnosis revelation to the adolescents and coping with HIV/AIDS from the family caregivers' standpoint. These themes will be presented and discussed, supported by references pertinent to the topic.

\section{ANALYSIS AND DISCUSSION}

The adolescent process with HIV/AIDS from the adolescent standpoint

Adolescence is a process filled with physical and psychosocial changes important forindividual development and, similar to other phases, shows crises, which especially occur in function of the bodily changes that influence the relationships with the social environment, which the adolescents seek to join more thoroughly as from this period ${ }^{(6)}$.
Growth and development of adolescents with HIV/ AIDS

Human development, without considering the circumstances the individual is exposed to, is a cycle involved by remarkable transition periods. Adolescence, as part of this cycle, represents an important transition phase, which is evidenced by increased physical development - the pubertal growth spurt- and by important and influential bodily changes. Emotionally and socially, the adolescent also undergoes transitions triggered by inner and external conflicts, which exposes the possibility of experimenting situations, preparing them to face other responsabilities when reaching adulthood.

Referring to adolescence with AIDS, the conflicts typical of this period, added to coping with AIDS, make the adolescent become overwhelmed with uncertainties and omnipotency, due to the consequences of the HIV infection. "For the young person infected by the Human Immunodefficiency Vírus (HIV), the uncertainties typical of this development phase are added to those brought by the infection, whose effects are still life-threatening"(7).

Concerning growth and physical development of children and adolescents affected by HIV, they behave differently when compared with healthy individuals of the same age. These aspects were observed from the contact with the adolescents in this study, who showed physical development below expected levels. The females were physically alike younger children and without the significant characteristics of puberty related to sexuality, at least not observed/felt by them. It can be observed in the report of this adolescent with HIV: She (the mother) said I would become a young lady [...] (laughs) (Adolescent 4).

The expression "become a young lady" presupposes this adolescent is aware of the bodily changes indicating her arrival in adolescence. However, in her report about the characteristics said to be typical of the phase, she seems not to recognize herself in this phase, due to her physical appearance similar to a younger girl.

This lack of recognizing herself as an adolescent arouses questions about how socializing instances $^{(2)}$ - family and school - are contributing to the biopsychosocial development process of these adolescents with HIV. As evidenced by the reports, the theme of bodily change is little discussed in these (in)formation media. 
The adolescents in this study also recalled affective relationships, seen as an integral part of adolescent development and represented by "having a date" and/or dating. "Having a date" is a relationship without commitment, whose objective is the search of pleasure. It is the easiest way to approach someone without commiting, and this relationship is an exercise of seduction ${ }^{(8)}$.

The understanding of this love relationship typical of adolescence seem to be clear among some adolescent in this study: If a guy comes to ask me to kiss him on that day, I go and stay with him only that day, but we are not going steady. It is all about hugging, touching and kissing, nothing else (A4); It is only for a day and period. (Adolescent 3).

Thus, the "date" represents, for most young people, a moment of learning and experiencing pleasures inherent to affective love relationship typical of adolescence, which is known and experienced by some adolescents in the study.

I have been on a date many times [...] The other day a guy said: 'ask your girlfriend to go steady with me'. Then I thought and thought and said yes. But, it was not serious, we were together one day and he said he was dating me. (Adolescent 4)

In this study context, the occurrence of sexual intercourse, when they were together, was not mentioned. An adolescent had observed on a television show a scene in which the actors insinuated sexual intercourse. It presupposes she was aware of that situation: In the soap apera, they showed the woman lying in bed, teasing him in bed [...] playing some scenes (Adolescent 4).

This expression "teasing him" seems to be understood by the adolescent as the female behavior to conquer a man, which evidences that television shows, especially soap operas, convey information about male and female behavior.

A research developed by the United Nations Children's Fund (UNICEF), involving around 5,000 Brazilian adolescents of both genders, in different regions, showed television as the second most important source of adolescent leisure and entertainment, especially soap operas and mini series $^{(9)}$.

Regarding the media's influence on the behavior of children and adolescents, "the sexual universe in the media eventually eroticizes child behavior, more than their minds"(10). It can be said that the media is omnipresent, influencing the behavior of children and young people during their development, broadcasting information, often urging the representation of this behavior without promoting reflection among the adolescents.

The adolescents in this study were also questioned about the knowledge of contraceptive methods and protection against STD, information that should be clear because it is related to the viability of affective love relationships. In this study, some adolescents demonstrated little knowledge of the topic, which was also acquired by means of information broadcast by the media. I have already heard of the pill and the condom, which I have seen on TV (Adolescent 3); The medicine, the shot, I do not know what they put into your arm and the woman does not get pregnant. [...] (Adolescent 4).

This study evidences that, again, it are the media that broadcast information regarding contraceptive methods and STD protection. A study on the awareness of contraceptive methods, developed with adolescent students of public schools in Aracajú(11), demonstrated that this information is obtained, mostly, by TV, radio and newspapers and magazines. It also showed that the lack of dialogue opportunities in the family core makes the adolescents search for information in other sources, as an attempt to clarify doubts related to this theme. Hence, in both cases, the media seem to be the most successful information means of these adolescents.

Coping with HIV/AIDS: the diagnosis revelation, the adolescent feelings and reactions

The impact of a chronic disease for the child depends on the level of development, as well as the moment when the disease began and the experience accummulated by the child with the disease. Among the adolescents, coping with a chronic disease may affect the relationship and acceptance by the group of friends, also interfering in the adolescents' feelings about their body domains. The adolescent experiences a phase of discovery, a search for identity, becoming more vulnerable to emotional stress ${ }^{(12)}$.

In society, a stigma still rests on HIV/AIDS. Therefore, the revelation of the diagnosis and coping with the disease, regardless of age, initially arouses a reaction of non-acceptance in the patient. This type of reaction may trigger feelings and reactions of sadness, inconformity, embarrassment and acceptance further ahead. Among the adolescents participating in this study, the manifestation of such feelings is noticed. I feel rather sad. Why did my mom do this to me? (Adolescent 3) 
Sadness, the feeling expressed by this adolescent, is the basic human feeling, characterized as "unpleasantry before loss or failure"(13). Such loss is translated in the study as that of a life considered "healthy", "equal" to that of other adolescents of the same age, with all the situations involved in this phase.

Another adolescent in the study, whose diagnosis was revealed by the mother still in childhood, seems to have resigned to the HIV/AIDS situation: It is not that I get sad. This is my life, right? (Adolescent 4)

It is important to consider that the time of diagnosis revelation influences the manifestation of these feelings, given that adolescent 3 had her diagnosis revealed a short time before the interview, justifying her sadness and discomfort when discovering the disease. Other adolescents in the study (1, 2 and 4) have coped with HIV/AIDS since childhood and seem to be experiencing the acceptance phase of the disease. However, all of them show some anguish related to life routines, modified in function of AIDS and the care inherent to the disease, as evidenced by their silence when more in-depth questions were asked about the diagnosis and coping with the disease.

The adolescent process with HIV/AIDS from the family caregivers' standpoint

The adolescent process implies the understanding of the individual and family about this period filled with conflicts that involve key biopsychosocial changes. Regarding adolescents with HIV/AIDS, the conflicts typical of this period are added to those triggered by coping with the disease, when it comes to manifestation and treatment. These aspects require some adolescent commitment and should receive suitable social support by the family when facing the disease that influences development.

- Growth and development of adolescents with HIV/ AIDS from the family caregivers' standpoint

The adolescent growth and development process, besides the significant bodily changes in this phase, the search for a group identity, the interest in living an affective love relationship and the need for information about themes related to sexuality, should be topics contemplated by the family, due to the discussions typical of this development phase.
The caregivers' participating in this study were questioned about the occurrence of a dialog about "having a date/going steady" in the family core. Their reports stated that relationships involve physical and emotional maturity of the person, and also a trust relationship among the family members: (...) nowadays, it is not anyone and talking does not kill, but having a date, going steady, we have to worry, even more about children who do not know what they want (Caregiver 1). I still see her as a very little girl to go steady. At thirteen, I believe she is already quite mature (Caregiver 3); She has never had a date, she has never gone steady. She is not ready to go steady and when the time comes I will let her go steady (Caregiver 2).

In the caregivers' viewpoint, the right moment to "have a date/go steady" is related to the adolescent's age and bodily maturity, but the suitable moment to begin these relationships was not clear. Apparently, there is not an objective discussion about the topic that feeds further discussions about sexuality. It should be pointed out that, concerning love relationships, there is the perception that, for these caregivers, there is a right moment, but not for the adolescents.

It is seen that, just like with other adolescents, the triggering and discussion of these subjects in the family core is still problematic and hard for the parents/caregivers, and also for children in the universe of adolescents with HIV. Although parents are concerned with their children regarding the discussion of these questions, there is not a preparation to begin the dialog with delicate questions which offer an opportunity to discuss other themes related to adolescent sexuality and love relationships ${ }^{(14)}$. As to bringing up other subjects, such as disease exposure and teenage pregnancy, two caregivers showed knowledge acquired from life experiences. They reinforce concern with the adolescents, making them aware of the problems that may appear from a teenage pregnancy or exposure to sexually transmitted diseases. [...] what the mind does, the body pays and an underaged child with a child, a child looking after another child, it is a big responsibility. I have lived through this, I know what it is and I could not avoid pregnancy. (Caregiver 1) I talked about the use of condoms, but not about the pill. Because, if she uses the condom, there is not the risk (of infection and other diseases), because she uses the female condom. What I know, what I have learned, I tell her. (Caregiver 3).

However, another caregiver informed she had not had a dialog with the adolescent about these topics, 
because she thinks that the adolescent did not show interest: [...] I did not talk about condoms and pills because I don't see her talking about boys, about anything and I can't go into a subject she has not started. (Caregiver 2)

There is hidden fear to talk about these questions in this caregiver's report, due to the fact that the adolescent has HIV. This seems to be, in the caregiver's perspective, a limiting factor for the start of a dialog about this theme.

- Revealing the diagnosis to the adolescents and coping with HIV/AIDS from the family caregivers' standpoint

The revelation of the HIV/AIDS diagnosis triggers family expectations regarding the child or adolescent's reactions. These reactions depend on the understanding of the disease and the consequences it imposes for the biopsychosocial development. Among the adolescents in this study, three had the diagnosis revealed still in childhood and one only in adolescence, in function of menarche.

In the revelation of the HIV diagnosis to the adolescents in this study, the caregivers described different reactions. She laughed (Caregiver 1); The mother said that when the doctor told her, she got desperate [...] I talked with her later, some days later, and she began to cry. I said this is normal and I guess she resigned (Caregiver 2). She cried a lot, she hugged me. She told me we both had to take care and I was going to take care of her and the other way around (Caregiver 3).

The adolescents' reactions can be understood as pertinent to the adaptive stages initiated with the diagnosis of a chronic disease in which the "initial stage is extremely emotional". "Acting happily and optimistically, despite the diagnosis revealed" also suggests that the individual is living through the denial phase of the disease ${ }^{(12)}$.

However, the fact of resigning and understanding AIDS as something normal, allows to infer that caregiver 3 is not well-adjusted to the adolescent's diagnosis either. It may include partial denial, which acts as a temporary protection mechanism, allowing people to receive stressful doses of information by themselves, so as to control their feelings at the moment of the diagnosis ${ }^{(12)}$. Besides the emotional reactions shown by the adolescents, one of the caregivers indicated fear and embarrassment due to the social stigma of the disease, which is extended to the family, as factors limiting the diagnosis revelation. The mother had to transfer her because their friends would say 'she has AIDS because her mother died of AIDS' [...]. Then, as she endured discrimination, my mom took her out of that school and at the school she is now, nobody says anything (Caregiver 2).

The fact that "nobody says anything", and the non-indication of the adolescent as an HIV/AIDS carrier also imply that other relatives are putative virus carriers. This attitude evidences that some protection is extended to this adolescent's family

The disease awareness by relatives or people in the social environment remains a reason for discrimination, according to two caregivers who mentioned some prejudice against the disease in the family core.

My family, my true friends, who are few, know. I do not think you should tell everyone in town you have it, because there is prejudice (Caregiver 3 ).

You know what it's like, there are comments in the family. [...] If they say something, they say it for the whole neighborhood to know (Caregiver 1 ).

The revelation of the HIV diagnosis in the family and social core is implicitly said to be discriminatory in the caregivers' reports. Apparently, neither the family nor the social environment understands AIDS as a chronic disorder that should be handled without fear. It is a disease that, due to its history, still causes embarrassment and social isolation, which are extended to the family network when one of its members has HIV.

This discriminatory and stigmatizing feeling was identified in a study of adolescents with HIV/AIDS and their caregivers ${ }^{(15)}$, who endured discriminatory experiences in their family and in the social environment, represented by friends, school, work and health services.

Regarding the caregivers' perception about coping with adolescents with HIV, this coping may imply in taking attitudes to protect the adolescents and the family against discrimination and the representations AIDS arouses in society.

Due to social judgment and in the attempt to protect the adolescents, these caregivers show difficulties to inform the HIV to the family and the social context. They attempt to avoid the young people's exposure, which may implicitly influence the normal course of adolescence when it comes to sexuality, group involvement, body awareness and its changes. These aspects, due to the presence of the virus, seem to demand more attention from the family, school and health services. 


\section{FINAL CONSIDERATIONS}

The study allowed an approximation with the universe of adolescents with HIV/AIDS, born at a time when seroconversion was not possible. Maybe, for this reason, prolonged survival was not expected, and there was not a clear concern with the development process and its inherent changes.

As evidenced by the contact with these adolescents, they seem not to understand well that they are entering a period of intense bodily changes, which will influence their development. Despite their opinions about some bodily changes, knowledge of some contraceptive methods and comprehension of the difference between having a date and going steady, there is a clear failure to bring up these subjects in the family, school and also health services.

As adolescence is a step characterized by immediateness and magic thought, living the current moments alone can be enough to meet the possibilities of existing.

\section{REFERENCES}

1. Ramos FRS, organizadora. Adolescer: compreender, atuar, acolher. Brasília (DF): ABEn; 2001.

2. Setton MGJ. Família, escola e mídia: um campo com novas configurações. Educ Pesqui 2002 junho; 28(1):107-16.

3. Barrero CEA. Crianças vivendo com HIV e casas de apoio em São Paulo: cultura, experiências e contexto domiciliar. Interface - Comunicação e Saúde 2002 agosto; 6(11):5570.

4. Creswell JW. Projeto de pesquisa: métodos qualitativo, quantitativo e misto. $2^{\text {a }}$ ed. Porto Alegre (RS): Artmed; 2007. 5. Bardin L. Análise de conteúdo. Lisboa (Portugal): Edições $70 ; 1995$

6. A AIDS na adolescência. Revista Boa Saúde [seriado online] 2003 dez [Acessado em 17 abr 2006]; [01 página].Disponível em: URL: http://boasaude.uol.com.br

7. Baricca AM. Vivendo e crescendo com HIV/AIDS. [tese]. São Paulo (SP): Programa de Pós-Graduação em Ciências da Coordenação dos Institutos de Pesquisa da Secretaria de Estado da Saúde de São Paulo; 2005.

8. Chaves J. Ficar com: um novo código entre jovens. Rio de Janeiro (RJ): Revan; 1997.

9. Fundo das Nações Unidas para a Infância (UNICEF). Niños y niñas: el rostro oculto del SIDA. UNICEF [série online] 2005 [acessado em 23 fev 2006]; [28 folhas]. Disponível em: URL: http://www.unicef.org

10. Furlani J. Educação Sexual. [série online] 2003 [acessado em 28 fev 2006]; [10 folhas]. Disponível em URL:http:// www.jimena.net/educacaosexual_html.
In relation to the diagnosis and coping with the virus, the caregivers expressed concern with maintaining the diagnosis hidden, including to people in the family, given that they understand that a social stigma still rests on the disease, which leads to judgements and discrimination that strike not only the adolescent, but also the family.

By involving social commitment, this study suggests that professionals and educators involved in the HIV/AIDS theme, should develop a deeper understanding of adolescence questions in order to implement measures focused not only on the treatment of the disease, but also on the inclusion of aspects related to education of these adolescents' caregivers, responsable for care that influences their biopsychosocial development. Providing support and information to caregivers can help them to establish a clear dialog with these adolescents who, like others, require attention and objective information about changes inherent to this development phase.

11. Guimarães AMN, Vieira MJ, Palmeira JA. Informações dos adolescentes sobre métodos anticoncepcionais. Rev Latino-am Enferm 2003 maio-junho; 11(3):293-98.

12. Wong, DL. Enfermagem pediátrica: elementos essenciais à intervenção efetiva. $5^{a}$ ed. Rio de Janeiro (RJ): Guanabara Koogan; 1999.

13. Martins JM. A lógica das emoções na ciência e na vida. Petrópolis (RJ): Vozes, 2004.

14. Cano MAT, Ferriani MGC. A família frente a sexualidade dos adolescentes. Acta Paul Enferm 2000 janeiro-abril; $13(1): 38-46$.

15. Marques HHS, Silva NG, Gutierrez PL, Lacerda R, Ayres JRCM, DellaNegra $M$, et al. A revelação do diagnóstico na perspectiva dos adolescentes vivendo com HIV/AIDS e seus pais e cuidadores. Cad Saúde Pública 2006 março; 22(3): 619-29. 